\title{
Ecological determinants of butterfly vulnerability across the European continent
}

\author{
Tijl Essens ${ }^{1} \cdot$ Frank van Langevelde $^{2} \cdot$ Rutger A. Vos $^{3} \cdot$ Chris A. M. Van Swaay $^{1}$. \\ Michiel F. WallisDeVries ${ }^{1,4}$
}

Received: 14 June 2016 / Accepted: 21 March 2017 / Published online: 30 March 2017

(C) The Author(s) 2017. This article is an open access publication

\begin{abstract}
In drawing up Red Lists, the extinction risks of butterflies and other insects are currently assessed mainly by using information on trends in distribution and abundance. Incorporating information on species traits may increase our ability to predict species responses to environmental change and, hence, their vulnerability. We summarized ecologically relevant life-history and climatic niche traits in principal components, and used these to explain the variation in five vulnerability indicators (Red List status, Endemicity, Range size, Habitat specialisation index, Affinity for natural habitats) for 397 European butterfly species out of 482 species present in Europe. We also evaluated a selection of 238 species to test whether phylogenetic correction affected these relationships. For all but the affinity for natural habitats, climatic niche traits predicted more variation in vulnerability than life-history traits; phylogenetic correction had no relevant influence on the findings. The life-history trait component reflecting mobility, development rate, and overwintering stage, proved the major non-climatic determinant of species vulnerability.
\end{abstract}

Electronic supplementary material The online version of this article (doi:10.1007/s10841-017-9972-4) contains supplementary material, which is available to authorized users.

Michiel F. WallisDeVries

michiel.wallisdevries@ vlinderstichting.nl

1 De Vlinderstichting/Dutch Butterfly Conservation, P.O. Box 506, 6700 AM Wageningen, The Netherlands

2 Resource Ecology Group, Wageningen University, P.O. Box 47, 6700 AA Wageningen, The Netherlands

3 Naturalis Biodiversity Center, P.O. Box 9517, 2300 RA Leiden, The Netherlands

4 Laboratory of Entomology, Wageningen University, P.O. Box 16, 6700 AA Wageningen, The Netherlands
We propose that this trait component offers a preferable alternative to the frequently used, but ecologically confusing generalist-specialist continuum. Our analysis contributes to the development of trait-based approaches to prioritise vulnerable species for conservation at a European scale. Further regional scale analyses are recommended to improve our understanding of the biological basis of species vulnerability.

Keywords Life-history traits · Phylogeny · Vulnerability · Conservation $\cdot$ Red List $\cdot$ Butterflies

\section{Introduction}

The worldwide decline of biodiversity leads to losses of a broad array of ecosystem services, such as pollination in agricultural landscapes and recreational and cultural benefits (Nelson et al. 2009; Cardinale et al. 2012; Garibaldi et al. 2013). The European strategy and the Convention on Biological Diversity (CBD) aim to halt biodiversity loss by 2010-2020 (Balmford et al. 2005; European Commission 2011). Accomplishing this objective requires both continuous assessment of biodiversity status and ecological understanding of species' vulnerability in relation to their environmental drivers. Threat status is currently assessed using the IUCN Red List methodology, with increasingly reliable data from national to continental scales (IUCN 2005; Rodrigues et al. 2006; Keith et al. 2015). Data on insects are still limited, despite signals that insects are particularly sensitive to environmental change (Thomas et al. 2004; Settele et al. 2008; Rasmont et al. 2015). Butterflies form the exception as their biology is comparatively well studied over a wide range of species, and their conservation status is primarily based on population trends and 
distribution changes derived from decades of systematic monitoring (Van Swaay et al. 2008, 2010, 2011). At present, 37 butterfly species are listed as threatened in the Red List for Europe (9\%), but national trends in abundance indicate alarming declines in many species; e.g., $48 \%$ in the Netherlands since 1992 and 76\% in the UK since 1976 (Fox et al. 2015; Van Swaay et al. 2016). Moreover predictive scenarios of increased economic development and climate change suggest that as much as $78 \%$ of European butterfly species may lose $>50 \%$ of their climatic niche area by 2080 (Settele et al. 2008).

The growing recognition that the persistence of butterfly populations strongly depends on species' intrinsic life-history traits to cope with environmental change, has provided scientists the opportunity to derive a mechanistic understanding of past and future species population and distribution trends (e.g., Roy et al. 2001; Mattila et al. 2008; Diamond et al. 2011; Newbold et al. 2012; Nieto-Sánchez et al. 2015; De Palma et al. 2015; Eskildsen et al. 2015). In general, morpho-physio-phenological and behavioural traits impact fitness via their effects on growth, reproduction and survival (Violle et al. 2007). Therefore, a set of life-history traits within a species is likely to be the outcome of longterm environmental selection of fitness and performance qualities for a population to persist, limited by the available phylogenetic space of individual species. Consequently, environmental gradients are often indicative for the composition of traits in species (Carnicer et al. 2013; Leingärtner et al. 2014). Trait-continua in various animal taxa picture arrays of specialized to more generalist species and/or from slow to fast life-styles, and are likely the result of growth versus survival trade-offs (Blackburn 1991; Wright et al. 2004; Devictor et al. 2008; Bielby et al. 2007; Sæther et al. 2011; Janz and Nylin 2008), though some apparently correlated traits may actually consist of independently evolved strategies (Kraft et al. 2007). Environmental alterations in the short term are likely to filter out Lepidoptera species that display a narrow niche breadth (food and habitat), slow development and sedentary behaviour (e.g., Mattila et al. 2006, 2011; Warren et al. 2001; Bartonova et al. 2014; WallisDeVries 2014). Conversely, butterfly species equipped with a set of adaptive traits, including high dispersal capacity, multiple generations per year and broad trophic as well as thermal niches, have the potential to expand their range and initiate adaptive radiations (e.g., Börschig et al. 2013; Ohlemüller et al. 2008).

Widespread environmental change and international butterfly conservation efforts challenge us to scale up traitbased studies across the European continent. Here, we establish the relationships between butterfly trait components and species vulnerability indicators (Red List status, endemicity, range size, habitat specialisation, natural versus anthropogenic habitat). We tested whether (i) species can be ordered along ecological trait components (e.g., specialized to more generalist species, slow to fast life styles, low to high mobility, narrow to broad climatic requirements), (ii) these trait components may explain a major part of the variation in butterfly vulnerability, and (iii) the extent to which correlative patterns between traits and vulnerability indicators are shaped by phylogenetic dependency. We consider the latter because, when comparing traits across species, the possibility must be taken into account that the observed distribution of trait values is not shaped by selection, but by auto-correlation caused by shared ancestry: trait characteristics of different species might resemble one another merely because the species are closely related rather than because of a common selective regime. Hence, it has been recommended to assess the pattern of genetic relatedness and, when relevant, use it as a correction factor in comparative trait analyses (Harvey and Pagel 1991).

\section{Methodology}

\section{Species traits}

For 397 European butterfly species, we incorporated five traits associated with species' climatic preferences (i.e., climate optima and breadth of organisms) and six traits associated with species' life history (i.e., morphological, physiological, phenological and behavioural adaptations innate to an organism) (Table 1, Supplementary Material Table S1). Climatic niche traits were adopted from Schweiger et al. (2014) and included species-specific niche optima and breadth for temperature, precipitation and soil water moisture content in the distribution area. For temperature and precipitation, we selected the annual mean and sum respectively, as well as the mean annual range, in order to capture the main climatic variation along gradients of latitude, elevation, and continentality (Schweiger et al. 2014).

Life-history traits included average male/female forewing length and egg volume. Wing size and dispersal are positively associated (Sekar 2012; Altizer and Davis 2010), while egg size can act as a phylogenetic corrective for wing size, given the relationships between wing size and egg size for many butterfly subtaxa (García-Barros 2002). Larval diet breadth is an important limiting factor in butterfly vulnerability, in terms of range size, dispersal capacity and landscape use (e.g., García-Barros and Romo Benito 2010). Species phenology is associated with colonisation ability, ranging from restricted climatic environments to wide distributions across a variety of climatic environments. Phenological traits included voltinism (i.e., the average number of generations per year) and overwintering stage (i.e., indicating how early species can reproduce in the season). 
Table 1 Species traits and indicators for species vulnerability used in this study

\begin{tabular}{|c|c|c|c|}
\hline & Variables & Data scale & Values \\
\hline \multirow[t]{6}{*}{ Life-history traits } & Vagrancy & Ordinal & $\begin{array}{l}\text { (1) Rare record ex habitat, (2) occasional colonization events over }<10 \mathrm{~km},(3) \text { urban } \\
\text { areas and gardens, (4) occasional colonization events over }>10 \mathrm{~km},(5) \text { rapid range } \\
\text { expansions over }>100 \mathrm{~km} \text { in } 10 \text { years, (6) short-distance overseas dispersal-at sea } \\
\text { records-island populations, (7) incidental long-distance (mass) movements, (8) } \\
\text { regular reversed long distance migrations }\end{array}$ \\
\hline & Voltinism & Ordinal & (1) 0.5 , (2) 1 , (3) $1-2$, , (4) 2, , (5) $2-3$, (6) $3-4$ (generations per year) \\
\hline & Overwintering & Ordinal & $\begin{array}{l}\text { (1) Egg, (2) first instar larva, (3) half-grown, (4) last instar, (5) pupa, (6) adult, (7) no } \\
\text { hibernation }\end{array}$ \\
\hline & Wing size & Continuous & $\mathrm{mm}$ (average male / female) \\
\hline & Egg volume & Continuous & $\mathrm{mm}^{3}$ \\
\hline & Specialisation & Ordinal & $\begin{array}{l}\text { (1) Polyphagous (multiple species, }>1 \text { plant family), (2) polyphagous (multiple spe- } \\
\text { cies, } 1 \text { plant family), (3) oligophagous, (4) monophagous }\end{array}$ \\
\hline \multirow[t]{5}{*}{ Climatic niche traits } & Temperature index & Continuous & ${ }^{\circ} \mathrm{C}$ (monthly average across species range) \\
\hline & Precipitation sum & Continuous & mm (annual sum across species range) \\
\hline & Temperature range & Continuous & ${ }^{\circ} \mathrm{C}$ (maximum-minimum monthly average across species range) \\
\hline & Temperature range & Continuous & mm (maximum-minimum monthly average across species range) \\
\hline & Soil water content & Continuous & Units $0-1$, water availability in the upper horizon $(0.5 \mathrm{~m})$ \\
\hline \multirow[t]{5}{*}{ Vulnerability indicators } & Red List status & Binary & $\begin{array}{l}(0-1) ;(0) \text { Least concern, (1) near threatened, vulnerable endangered or critically } \\
\text { endangered }\end{array}$ \\
\hline & Range size & Continuous & Occupancy in number of $50 \mathrm{~km}^{2}$ grid cells \\
\hline & Endemicity & Binary & (1) European endemics, (0) species also occurring outside Europe \\
\hline & Habitat use & Binary & (0) Natural, (1) anthropogenic \\
\hline & Habitat specificity & Continuous & SSI index ${ }^{a}$ \\
\hline
\end{tabular}

${ }^{\text {a }}$ See text

Vagrancy reflects dispersal capacity and landscape use, and was based on a slightly adapted version of the classification by Dennis et al. (2004), complemented by expert knowledge for a total of 220 species. Based on species with known trait information, we used a linear regression model with voltinism, wingspan and range size to explain vagrancy with available data, and predicted vagrancy for the remaining 177 species $\left(\mathrm{R}^{2}=0.505, \mathrm{df}_{1,219}, \mathrm{SE}=1.128\right)$, using the following equation (with all variables significant at $\mathrm{p}<0.0001)$ :

$$
\begin{aligned}
\text { Vagrancy }= & -0.472+0.482 \times(\text { Voltinism }) \\
& +0.44 \times(\text { Wingspan })+0.001 \times(\text { Range Size })
\end{aligned}
$$

\section{Species vulnerability}

Vulnerability indicators included Red List status, Endemicity, Range size, Affinity for natural habitats and Habitat specificity (Table 1). The Red List status, Endemicity and Range size were adopted from Van Swaay et al. (2010); in further analyses Red List status and Endemicity were treated as binary values (Red List status: 1 if 'Near Threatened' or higher threat category, Endemicity: 1 for European endemics), because of small sample size of individual categories. Affinity for natural habitats was derived from Van
Swaay et al. (2006) as recorded occurrence in CORINE biotopes (Moss and Wyatt 1994). Species were categorized into users of (1) natural landscapes and (2) agricultural land and artificial landscapes (see details in Supplementary Material Table S2). Habitat specificity was assessed on the basis of the above-mentioned habitat use data by Van Swaay et al. (2006), using the species specialisation index (SSI) (Julliard et al. 2006); the SSI takes into account variation in density among occupied habitats, assuming equal densities in occupied habitat and null densities in others. Values for wing size, egg size, range size and SSI were $\log _{10}$-transformed prior to analysis.

\section{Phylogenetic inference}

To obtain an estimate of phylogeny, we re-used the results of a recent survey of gene genealogies of the cytochrome oxidase I (COI) barcode marker in European Lepidoptera (Mutanen et al. 2016). Because the authors relied on computationally intensive methods of phylogenetic inference and incorporated numerous haplotypes per species, scalability constraints required their analyses to be partitioned into a number of monophyletic higher taxa. However, in our comparative analysis, we require a single, composite estimate. We synthesized this following a two-step 
approach, similar to Antonelli et al. (2016), by first inferring a backbone tree and then grafting the trees for the monophyletic higher taxon partitions from Mutanen et al. (2016) onto it. To obtain input data for backbone tree inference, we subsampled exemplar taxa from each of the higher taxon partitions and aligned their COI sequences using MUSCLE (Edgar 2004), under default settings. COI generally aligns without problems, and this was the case here as well, as visual inspection demonstrated. From this alignment, we constructed a starting tree that we optimized with the "best" hill-climbing algorithm of PhyML (which picks the optimal topology recovered from either NNI or SPR branch swapping, Guindon et al. 2010) under a GTR $+\gamma$ substitution model (Tavaré 1986). This starting tree we then provided as input for RAxML (Stamatakis 2014), which further improved the topology (under the same GTR $+\gamma$ substitution model). On the thus constructed backbone topology we then grafted the gene tree estimates from Mutanen et al. (2016). Since these gene trees include multiple haplotypes per species we first collapsed these to species level, under a conservative approach where, in every case where haplotypes from different species were entangled (i.e. cases of polyphyly or paraphyly), these were collapsed to a multifurcation that included all entangled species. Our results for this backbone generally reflect our understanding of the systematics of the taxa in our sample (Supplementary Material Fig. S1). Lastly, in order to obtain an ultrametric estimate of phylogeny whose branch lengths are proportional to evolutionary time, we performed a rate smoothing procedure using penalized likelihood as implemented in r8s (Sanderson 2003). For this analysis we used the truncated Newtown algorithm and incorporated eight calibration points (ranging between 48.5 and 224 MYA), which we obtained from the TimeTree database (Hedges et al. 2006).

When reconciling the taxa in this grafted tree with those for which trait data (described below) were available, we needed to prune numerous taxa from the tree, lowering the number of tips from 4970 to 238 , out of which three were taxonomically synonymized, to wit, Cupido decolorata (also in usage is the specific epithet $C$. decoloratus), Erebia aethiopellus (alternatively, E. aethiopella), and Agriades aquilo (alternatively, Plebejus aquilo) (Table S1).

\section{Statistical analysis}

We applied principal component analysis (PCA) to assess the scores of individual species along the main orthogonal axes of adaptive species traits (Table S1). We separated life-history and climatic niche traits in order to assess their relative contributions. Variables with ordinal scale data were treated as continuous variables in the analysis, as it has been shown that PCA is robust to discrete data scales
(Kolenikov and Angeles 2004). For the dataset of 397 species, we used multiple linear least square regressions for continuous response variables and multiple logistic regression for binary response variables to identify the relative contribution of the species-specific PC values (predictive variables) to vulnerability indices (response variables). Quadratic terms of explanatory variables were included in the initial model to test for possible optimal response curves and subsequently eliminated if not significant.

The use of principal components as independent variables in a regression analysis is useful in situations where the original variables display high levels of collinearity. Since the principal components are orthogonal (uncorrelated), there is no multicollinearity in the regression. A number of studies have adopted this application of PCA in previous studies of species occurrence, distributions and vulnerability (WallisDeVries 2014; Shreeve et al. 2001; Maes et al. 2003; Kitahara and Fujii 2005; Summerville et al. 2006; Lütolf et al. 2009; Dapporto and Dennis 2013; Keddy et al. 2002; Oyarzabal et al. 2008). The relative contribution of trait components based on life-history vs. climatic niche traits in explaining the variance of each vulnerability indicator was calculated as their summed $\mathrm{F}$ values relative to total $\mathrm{F}$ value for the continuous variables Range size and Habitat specificity and as their summed $\chi 2$ values relative to total $\chi^{2}$ value for the binary variables Endemicity, Red List status and Affinity for natural habitats. Analyses were executed in JMP software (Sall et al. 2005).

The trend data underlying the European Red List rely to a substantial degree on expert opinion due to a lack of systematic monitoring data. Therefore, we checked if the obtained results of the multiple regression of vulnerability indicators against trait components at a European scale species were consistent with two more quantitative vulnerability indicators at the national scale in the Netherlands: Red List category (on a scale from 1 to 6; Bos et al. 2006) and abundance trend slopes for the period 1992-2015 from the Dutch Butterfly Monitoring Scheme (Van Swaay et al. 2016).

To account for potentially confounding effects of phylogenetic relatedness, we used the dataset of 238 species derived from the pruned phylogenetic tree, and included this information in the linear model using generalized least squares (GLS) implemented in the R package 'nlme' (Pinheiro et al. 2016) for the vulnerability indicators Range size and Habitat specificity. For each GLS, we checked for normality of the residuals. We used the option corPagel in the GLS to estimate Pagel's $\lambda$, which is used as a measure of the strength of the phylogenetic signal in the dependent variable (Symonds and Blomberg 2014). Depending on the lowest AIC score, we used either the restricted maximum likelihood (REML) or maximum likelihood (ML). For the other vulnerability indicators, Red List status, Endemicity 
and Habitat use, we used phylogenetic logistic regression (Phyloglm) as implemented in the R package 'phylolm' (Ho et al. 2016). Phyloglm reports $\alpha$ as a measure for the strength of the phylogenetic signal (Ives and Garland 2010).

\section{Results}

\section{Trait components from PCA}

For the life-history traits, three components explained $78 \%$ of trait variation among 397 butterfly species (Table 2). The first axis was strongly positively correlated to Vagrancy, Voltinism and Overwintering stage. The second axis was correlated to Size (wing and egg), whilst the third and least important axis was highly correlated to the degree of larval Food plant specialisation.

For the climatic niche traits, we found two equally important axes, explaining $88 \%$ of variation (Table 2). The first rotated axis was best represented by a negative

Table 2 Principal components of trait associations for 397 European butterfly species with correlation coefficients of trait variables with the rotated principal component axes

\begin{tabular}{|c|c|c|c|c|c|}
\hline \multirow[t]{2}{*}{ Rotated PCs } & \multicolumn{3}{|c|}{ Life-history traits } & \multicolumn{2}{|c|}{$\begin{array}{l}\text { Climate niche } \\
\text { traits }\end{array}$} \\
\hline & PC-LH1 & PC-LH2 & PC-LH3 & PC-C1 & $\mathrm{PC}-\mathrm{C} 2$ \\
\hline Variance & 1.99 & 1.68 & 1.01 & 2.20 & 2.19 \\
\hline$\%$ Explained & 33.2 & 28.0 & 16.8 & 44.1 & 43.7 \\
\hline Vagrancy & +0.83 & -0.26 & -0.10 & & \\
\hline Voltinism & +0.84 & +0.19 & +0.02 & & \\
\hline Overwintering stage & +0.71 & +0.04 & -0.05 & & \\
\hline Wingspan & +0.18 & -0.91 & +0.01 & & \\
\hline Egg volume & -0.21 & -0.86 & -0.07 & & \\
\hline $\begin{array}{l}\text { Food plant speciali- } \\
\text { sation }\end{array}$ & -0.08 & +0.04 & +0.99 & & \\
\hline $\begin{array}{l}\text { Range annual tem- } \\
\text { perature }\end{array}$ & & & & +0.92 & -0.05 \\
\hline $\begin{array}{l}\text { Range annual pre- } \\
\text { cipitation }\end{array}$ & & & & -0.85 & +0.05 \\
\hline $\begin{array}{l}\text { Species temperature } \\
\text { index }\end{array}$ & & & & -0.74 & -0.65 \\
\hline Soil water content & & & & +0.16 & +0.96 \\
\hline Annual precipitation & & & & -0.25 & +0.91 \\
\hline PC-C1 & -0.15 & +0.01 & -0.15 & & \\
\hline PC-C2 & -0.33 & -0.09 & -0.13 & & \\
\hline
\end{tabular}

The strongest correlations for each variable have been marked in bold Correlation coefficients between life-history and climatic niche trait components are listed below

$P C$ principal component of combined traits, $L H$ life-history, $C$ climatic niche traits relationship between Temperature range on the one hand, and Precipitation range and Species temperature index on the other. The second axis was also correlated to the Species temperature index and additionally to water availability through Annual precipitation and Soil moisture content. Thus, Species temperature index contributed to both axes.

The correlation between the life-history and climatic niche trait components was significant in four out of six cases $(\mathrm{p}<0.01$ for $\mathrm{r}>0.13)$, but its magnitude was low. The strongest correlation, $\mathrm{r}=-0.33$ between PC-B1 and PC-C2, suggests an association of species from cool, moist climates with life-history traits reflecting sedentary behaviour, producing a single generation per year and overwintering in early developmental stages; such trait combinations are typically found in arctic-alpine species.

\section{Relationship between traits and vulnerability indicators}

For the full dataset with 397 butterfly species, all five vulnerability indicators were strongly correlated or associated with each other $(\mathrm{p}<0.0001$; generally positively, with the evident exception for Range size which showed negative correlations and associations); only Endemicity ( $=0.35)$ and Habitat specificity (SSI; $\mathrm{p}=0.17)$ were not significantly different between species with and those without Red List status. The species-specific scores for life-history and climatic niche trait components (Table S1) were used to explain the variation in five vulnerability indicators. All five indicators were significantly related to a combination of several life-history and climatic niche trait components. In general, relative contributions from climatic niche traits were more important to explain species vulnerability than life-history traits, with the exception of the vulnerability indicator Affinity for natural habitats.

The explained variation in vulnerability indicators by the trait components was highly significant (Table 3 ). Between trait components, the phylogenetically determined size component PC-LH2 (wing size and egg volume) was the only one not significantly correlated with any of the vulnerability indicators. The contribution of trait components to the proportion of explained variation was mostly higher for climatic niche variables than for life-history traits, except for the affinity of species for natural habitats, which was mainly determined by life-history traits (Fig. 1). For the latter, the developmental traits were dominant, whilst Food specialism was least important for Affinity for natural habitats.

Red List status was least explained by the trait components, but the predicted occurrence of species on the Red List (at a threshold of $\mathrm{p}>0.50$ ) was still adequate $(83.4 \%$ of species correctly classified as endangered or not; kappa measure for agreement $0.16 \pm 0.06, p=0.0002$ ). Species were more likely to be on the Red List in cool and moist 
Table 3 Results of the multiple regression between species-specific vulnerability indicators and trait component values for 397 species of European butterflies

\begin{tabular}{|c|c|c|c|c|c|c|c|c|}
\hline \multirow[t]{2}{*}{ Variable } & \multirow[t]{2}{*}{ Regression type } & \multicolumn{3}{|c|}{ Life-history traits } & \multicolumn{4}{|c|}{ Climatic niche traits } \\
\hline & & PC-LH1 & PC-LH2 & PC-LH3 & PC-C1 & $\mathrm{PC}-\mathrm{C} 1^{2}$ & PC-C2 & $\mathrm{PC}-\mathrm{C} 2^{2}$ \\
\hline Red list status & Logistic & $4.8^{-}$ & $2.8^{\mathrm{ns}}$ & $0.1^{\mathrm{ns}}$ & $12.3^{+++}$ & & $5.0^{-}$ & $11.0^{+++}$ \\
\hline Edemicity & Logistic & $19.4^{----}$ & $1.5^{\mathrm{ns}}$ & $14.1^{+++}$ & $35.8^{----}$ & & $15.3^{++++}$ & \\
\hline Range size & Linear least Squares & $68.6^{++++}$ & $0.3^{\text {ns }}$ & $27.4^{----}$ & $128.4^{++++}$ & $172.8^{---}$ & $127.2^{++++}$ & $175.9^{--}$ \\
\hline Habitat specificity & Linear least Squares & $96.1^{----}$ & $0.9^{\text {ns }}$ & $6.0^{+}$ & $62.8^{----}$ & $51.4^{++++}$ & $23.9^{----}$ & $69.0^{++++}$ \\
\hline Affinity for natural habitats & Logistic & $63.0^{----}$ & $0.0^{\mathrm{ns}}$ & $6.7^{++}$ & $4.0^{-}$ & & $0.0^{\mathrm{ns}}$ & \\
\hline
\end{tabular}

Values are $\mathrm{F}$ values for least square regressions and Wald $\chi^{2}$-values for logistic regressions. Squared component terms were only included when significant

$P C$ principal component of combined traits, $L H$ life-history, $C$ climatic niche traits, $n s$ not significant

+ or $-\mathrm{p}<0.05 ;^{++}$or $--\mathrm{p}<0.01{ }^{+++}$or $---\mathrm{p}<0.001{ }^{++++}$or $-----\mathrm{p}<0.0001$

Fig. 1 Relative contribution (out of 100\%) of life-history traits (black bars) and climatic niche traits (grey bars) in explaining variation in vulnerability indicators for European butterfly species, based on $\mathrm{F}$ values for trait components from least square regressions and on Wald $\chi^{2}$ values for logistic regressions

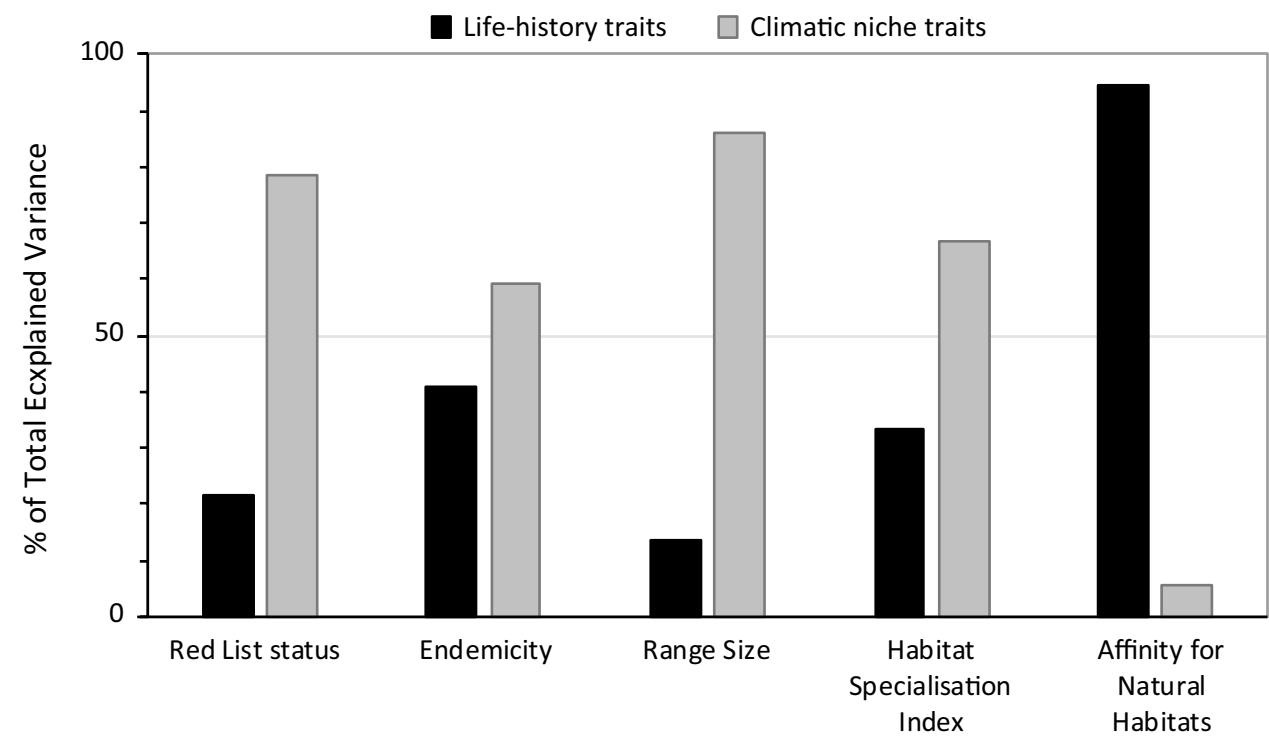

climates with high annual ranges in temperature and precipitation. All vulnerability indicators, with the exception of the Red List status, were higher for species with strong host plant specialisation. In contrast, vulnerability was lower for vagrant species, for species with large Range size as well as for multivoltine species overwintering at advanced developmental stages.

The response of vulnerability indicators to PC-C1 (annual temperature and precipitation range) was variable; positive for RL status, negative for species' Endemicity and Affinity for natural habitats and curvilinear for the other two vulnerability indicators. The results for Range size and Habitat specificity indicate that higher species vulnerability occurs at either low or high values of species-specific Temperature and Precipitation ranges. PC-C2 (moisture) also pointed to higher vulnerability at climatic extremes (dry / wet climates) for Red List status, Range size and Habitat specificity, whereas Endemicity was typically higher in wetter climates.

\section{Relationship between traits and vulnerability; the influence of phylogeny}

In general, the phylogenetic signal was weak; $\lambda$ (although significant in various cases) did not deviate much from 0 , while the values for $\alpha$ were low (Supplementary Material Table S3). We found a similar outcome for Red List status, Range size and Habitat specificity comparing the data of 238 species, with and without phylogenetic correction. The patterns in Endemicity and Affinity for natural habitats did deviate to some extent. Endemicity had a strong phylogenetic component in PC-LH2 (wingspan, egg volume), and consequently, the relationship between PC-LH2 and Endemicity was significant when correcting for phylogeny. In 
contrast, the relationship between Endemicity and PC-C2 (moisture) was not significant anymore with phylogenetic correction. In the case of Affinity for natural habitats, we found the association with PC-C1 (continentality) was also not significant anymore with phylogenetic correction.

\section{Application to trends in the Netherlands}

The Red List status of 73 species native to the Netherlands was explained significantly by the European traits $\left(\mathrm{R}^{2}=0.377\right)$ with $80 \%$ of the explained variation accounted for by the negative relationship with the life-history traits in PC-LH1 $(F=27.23, p<0.0001)$, i.e. a lower threat status at high values of PC-LH1. The climatic niche component PC-C1 was the only other factor contributing significantly with a negative effect $(F=5.34, p=0.024)$.

Abundance trend slopes of 40 species from the Dutch Butterfly Monitoring Scheme over the period 1992-2015 were explained to a lesser extent by the five trait components $\left(\mathrm{R}^{2}=0.260\right)$, with only PC-LH1 contributing significantly with a positive effect $(\mathrm{F}=7.19, \mathrm{p}=0.011)$, i.e., a more positive trend at higher values of PC-LH1.

\section{Discussion}

\section{Climatic dimensions of butterfly vulnerability}

We detected ecologically meaningful trait dimensions, and used these to explain variation in vulnerability indicators for 397 European butterfly species, equivalent to $82 \%$ of the 482 species currently recognized for Europe. The dimensions reflect climatic conditions, mobility, development rate and larval food specialisation. Size was a major, phylogenetically-based trait component, but was least relevant to explain species vulnerability. Climatic niche traits explained more variation in vulnerability indicators than life-history traits, except for species Affinity for natural habitats, which was mostly influenced by life-history traits.

We found that species restricted to the extremes of climatic gradients across the European continent are particularly vulnerable. In support of this result, the climatic rarity hypothesis (Willis and Whittaker 2000, amended by; Ohlemüller et al. 2008), postulates that centres of high species rarity coincide with unusual climate conditions that differ greatly from the surrounding areas. Various centres of high species rarity are higher and colder and harbour numerous isolated relics that presumably resulted from climatic warming since the last Ice Age. The organisms in these vulnerable areas will be affected disproportionally by environmental change.

For butterflies, areas of special conservation concern can be found in the Alps, Pyrenees and the Carpathians that face increasing temperatures, shorter snow seasons, and longer growing seasons (Ceppi et al. 2012; Brocard et al. 2013; Lindner et al. 2008; Gilbert and Vincent 2013; Beniston 2012). Consequently, species shift to higher elevations (Badeck et al. 2001; Wilson et al. 2005; Lenoir et al. 2010; Karolewski et al. 2007; Vanhanen et al. 2007), or northward in the case of boreal regions (EEA 2009). In addition, climatic variability may strongly impact insect development, predictability of food availability and phenological synchronicity between interdependent taxa (Walther et al. 2005; Vasseur et al. 2014). For the Alps, wetter winter/spring conditions in combination with drier summers are expected (Nemec et al. 2013; EEA 2009). Prolonged droughts are of particular concern for the Mediterranean, Central Europe and the Black Sea region, potentially leading to decreased growth rates, reduced fecundity and survival in insects (Cannon 1998; Ayres and Lombardero 2000; Bale et al. 2002; Parmesan 2006; Rouault et al. 2006). These aforementioned areas concur largely with three priority areas for conservation conveyed by traditional biogeography (Glacial Mediterranean refugia, Glacial refugia in the eastern Palearctic and arctic and/or alpine refugia to the North and/or into the high mountain systems), although more potentially important areas have been distinguished since (e.g., Schmitt and Varga 2012).

\section{Biological dimensions of butterfly vulnerability}

We found that among life-history traits, the trait component reflecting voltinism, overwintering stage and mobility explained a large share of variation in species vulnerability. This trait component also contributed most to explain the variation in well-documented population trends and Red List status of butterfly species in the Netherlands. To a lesser extent, the degree of larval food specialisation also constituted a significant factor determining species vulnerability at a European scale. These results are in agreement with the regional-scale analysis for Northwestern Europe (WallisDeVries 2014; see Supplementary Material Table S4 for correlations between trait components from that study with the present one), indicating that slowgrowing sedentary species are most at risk for the European continent. Similarly, Mattila et al. (2006, 2008, 2011) demonstrated that diet and habitat specificity, overwintering in larval and pupal stages and short flight period and body size predispose Lepidoptera in Finland to distribution decline. Other studies highlighted the role of hostplant growth form and life strategies in relation to butterfly development, voltinism and larval specificity (Dennis et al. 2004; Cizek et al. 2006, 2012; Bartonova et al. 2014). We propose that the abovementioned life-history trait component offers a suitable substitute to the widely used, but confusing specialist-generalist continuum (e.g. Dapporto and Dennis 2013). 
We find the term confusing and potentially misleading because the inferred specialisation does not have a biological basis, but is rather determined by the modern context of anthropogenic influence instead of the ecological conditions under which species have evolved (see WallisDeVries 2014). Indeed, we showed that species affinity with natural habitats was mainly determined by this trait component.

The low but significant correlation between climatic niche and life-history traits in this study may reflect the influence of climatic gradients on the coincidence of plant-host relationships and butterfly phenology. In agreement, butterflies from the Iberian Peninsula and the Alps, exhibit a trait continuum with altitude, ranging from multivoltine trophic generalists with high dispersal capacity and broad climatic niches, to univoltine, trophic specialist species with restricted dispersal and narrow climatic niches (Carnicer et al. 2013; Leingärtner et al. 2014).

\section{Phylogenetic component}

We used a selection of 238 butterfly species to investigate the need to correct for phylogenetic signals in the vulnerability analysis. We did not find it necessary to do so because after phylogenetic correction the results deviated little or not significantly from the results without correction. Moreover, using the phylogenetic correction would have forced us to exclude a substantial number of species (159) due to a lack of reliable phylogenetic data. Moreover, 12 of these missing species are either vulnerable, endangered or critically endangered (out of a total of 26 similarly threatened species). This was considered a serious disadvantage, because the results of the vulnerability analyses are especially relevant for endangered species. Therefore, we chose to adhere to the results without phylogenetic correction in order to cover the full set of documented species. Other studies also indicate that it is not always necessary to apply phylogenetic corrections in trait analyses (Mattila et al. 2006, 2011; Päivinen et al. 2005; Pavoine et al. 2014; Bartonova et al. 2014; Leingärtner et al. 2014; De Bello et al. 2015). This appears especially true for both this and the abovementioned studies that (partly) involve ecologically based traits, such as our climatic niche traits, which are less likely to be evolutionary conserved than morphological traits, such as body size.

\section{Challenges and opportunities in conservation}

Ecological trait-based approaches to species vulnerability pose certain limitations. Shifts in response to climate warming vary greatly among species, suggesting that range shifts depend on multiple species traits and external drivers of change (e.g. Chen et al. 2011), while potentially important traits may not be included for all species, due to gaps in knowledge of species ecology. Detailed trait information, such as was available for species from Northwestern Europe (WallisDeVries 2014), remains to be collected for many other European species. We did initially consider a number of additional traits (host plant growth form, aestivation, altitudinal limits, as well as other climatic variables, such as standard deviation of temperature and precipitation over a species' climatic range), but we decided to exclude them from the analysis due to methodological issues of trait variation and correlations between climatic variability and range size. Also, evolutionary plasticity of traits probably varies between species and between populations of the same species. Depending on the genetic variation and environmental pressure, traits continue to change. A final point of attention is that endemicity was typically higher in wetter climates, but as Europe constitutes the northwestern edge of the Palaearctic region, as good as all species preferring dry or steppic conditions are not endemic (most of them also occur in Asia or Africa), making endemicity a biased variable.

In spite of the limitations, this study clearly shows a weak response of the Red List status in relation to species traits, which begs the question if the Red List status should be more strongly rooted in a biological basis. An important candidate for improving underlying biological arguments, could be the trait complex of voltinism, overwintering stage and mobility. Here, we propose a tentative list of 56 candidate Red List species with below-median values for PC-B1 and for range size (Supplementary Material Table S5; a further 18 species meeting these criteria are already on the Red List). Similar attempts to predict extinction risk using multiple ecological traits, Kotiaho et al. (2005) for instance, revealed that threatened butterflies are characterized by narrow niche breadth, restricted resource distribution, poor dispersal ability, and short flight period. Thus, they were able identify seven vulnerable species for which the conservation status should be reconsidered in Finland.

Complementary regional analyses, for which specific trait information is more complete and climatic variation is less pronounced are still necessary to deepen our mechanistic understanding of species vulnerability. For the present study, the variation in climatic conditions across broad spatial scales was large, e.g., with respect to variation in continentality/oceanity with longitude or daily as well as seasonal variation in temperature and precipitation regimes with latitude and altitude (Settele et al. 2008; Schweiger et al. 2014). Again, it seems advisable to distinguish regions on ecologically relevant grounds in order to gain better understanding of the life-history traits that determine species vulnerability. Thermoclimatic conditions relevant to butterflies may, for instance, be incorporated as variables to select geographical areas for further disentanglement of life-history traits in spatially explicit studies. 
In conclusion, this analysis provides a basis to identify ecologically relevant species groups and prioritises vulnerable species for conservation at the European level. Although trait information is still limited at the European scale, our study indicates its potential to assess species vulnerability. Species vulnerability indicators were significantly determined by species-specific ecological traits, primarily climate requirements. Furthermore, the life-history trait complex reflecting mobility, development rate and overwintering stage proved another consistent determinant of species vulnerability that may be used to replace the anthropogenically determined specialist-generalist continuum. Further systematic regional scale analyses in different climatic zones are recommended as a next step to improve the biological basis for species vulnerability.

Acknowledgements The authors wish to thank Albert Vliegenthart of Dutch Butterfly Conservation, who kindly contributed his expert knowledge on butterfly mobility.

Open Access This article is distributed under the terms of the Creative Commons Attribution 4.0 International License (http:// creativecommons.org/licenses/by/4.0/), which permits unrestricted use, distribution, and reproduction in any medium, provided you give appropriate credit to the original author(s) and the source, provide a link to the Creative Commons license, and indicate if changes were made.

\section{References}

Altizer S, Davis AK (2010) Populations of monarch butterflies with different migratory behaviors show divergence in wing morphology. Evol Int J Org Evol 64:1018-1028

Antonelli A, Hettling H, Condamine FL, Vos K, Nilsson RH, Sanderson MJ, Sauquet H, Scharn R, Silvestro D, Töpel M, Bacon CD, Oxelman B, Vos RA (2016) Towards a self-updating platform for estimating rates of speciation and migration, ages, and relationships of taxa (SUPERSMART). Syst Biol. doi:10.1093/ sysbio/syw066

Ayres MP, Lombardero MJ (2000) Assessing the consequences of global change for forest disturbance from herbivores and pathogens. Sci Tot Environ 262:263-286

Badeck FW, Lischke H, Bugmann H, Hickler T, Höniger K, Lasch P, Lexer MJ, Mouillot F, Schaber J, Smith B (2001) Tree species composition in European pristine forests: comparison of stand data to model predictions. Clim Chang 51:307-347

Bale JS, Masters GJ, Hodkinson ID, Awmack C, Bezemer TM, Brown VK, Butterfield J, Buse A, Coulson JC, Farrar J, Good JEG, Harrington R, Hartley S, Jones HT, Lindroth RL, Press MC, Symrnioudis I, Watt AD, Whittaker JB (2002) Herbivory in global climate change research: direct effects of rising temperature on insect herbivores. Glob Chang Biol 8:1-16

Balmford A, Bennun L, Brink BT, Cooper D, Cote IM, Crane P et al (2005) The convention on biological diversity's 2010 target. Science 307:212-213

Bartonova A, Benes J, Konvicka M (2014) Generalist-specialist continuum and life history traits of Central European butterflies (Lepidoptera)-are we missing a part of the picture? Eur $\mathbf{J}$ Entomol 111:543-553
Beniston M (2012) Is snow in the Alps receding or disappearing? WIRES. Clim Chang 3:349-358

Bielby J, Mace GM, Bininda-Emonds OP, Cardillo M, Gittleman JL, Jones KE, Orme CDL, Purvis A (2007) The fast-slow continuum in mammalian life-history: an empirical reevaluation. Am Nat 169:748-757

Blackburn TM (1991) Evidence for a fast slow continuum of life-history traits among parasitoid hymenoptera. Funct Ecol 5:65-74

Börschig C, Klein AM, von Wehrden H, Krauss J (2013) Traits of butterfly communities change from specialist to generalist characteristics with increasing land-use intensity. Basic Appl Ecol 14:547-554

Bos FG, Bosveld MA, Groenendijk DG, Van Swaay CAM, Wynhoff I., De Vlinderstichting (2006) De Dagvlinders van Nederland: Verspreiding en Bescherming. Leiden: Nederlandse Fauna 7. Nationaal Natuurhistorisch Museum Naturalis, KNNV Uitgeverij and EIS-NL

Brocard E, Philipona R, Jeannet P, Begert M, Romanens G, Levrat G, Scherrer SC (2013) Upper air temperature trends above Switzerland 1959-2011. J Geophys Res 118:4303-4317

Cannon RJC (1998) The implications of predicted climate change in the UK, with emphasis on non-indigenous species. Glob Change Biol 4:785-796

Cardinale BJ, Duffy JE, Gonzalez A, Hooper DU, Perrings C, Venail P, Narwani A, Mace GM, Tilman D, Wardle DA, Kinzig AP, Daily GC, Loreau M, Grace JB, Larigauderie A, Srivastava DS, Naeem S. (2012) Biodiversity loss and its impact on humanity. Nature 486(7401):59-67

Carnicer J, Stefanescu C, Vila R, Dinca V, Font X, Peñuelas J (2013) A unified framework for diversity gradients: the adaptive trait continuum. Glob Ecol Biogeogr 22:6-18

Ceppi P, Scherrer SC, Fischer AM, Appenzeller C (2012) Revisiting Swiss temperature trends 1959-2008. Int J Climatol 32:203-213

Chen I-C, Hill JK, Ohlemüller R, Roy DB, Thomas CD (2011) Rapid range shifts of species associated with high levels of climate warming. Science 333:1024-1026

Cizek L, Fric Z, Konvicka M (2006) Host plant defences and voltinism in European butterflies. Ecol Entomol 31:337-344

Cizek O, Zamecnik J, Tropek R, Kocarek P, Konvicka M (2012) Diversification of mowing regime increases arthropods diversity in species-poor cultural hay meadows. J Insect Conserv $16: 215-226$

Dapporto L, Dennis RLH (2013) The generalist-specialist continuum: testing predictions for distribution and trends in British butterflies. Biol Conserv 157:229-236

De Bello F, Berg MP, Dias ATC, Diniz-Filho JAF., Götzenberger L, Hortal J, Ladle RJ, Lepš J (2015) On the need for phylogenetic 'corrections' in functional trait-based approaches. Folia Geobot 50:349-357

De Palma A, Kuhlmann M, Roberts SP, Potts SG, Börger L, Hudson LN, Lysenko I, Newbold T, Purvis A (2015) Ecological traits affect the sensitivity of bees to land - use pressures in European agricultural landscapes. J Appl Ecol 52:1567-1577

Dennis RLH, Hodgson JG, Grenyer R, Shreeve TG, Roy DB (2004) Host plants and butterfly biology. Do host-plant strategies drive butterfly status? Ecol Entomol 29:12-26

Devictor V, Julliard R, Jiguet F (2008) Distribution of specialist and generalist species along spatial gradients of habitat disturbance and fragmentation. Oikos 117(4):507-514

Diamond S, Frame A, Martin R, Buckley L (2011) Species' traits predict phenological responses to climate change in butterflies. Ecology 92:1005-1012

Edgar RC (2004) MUSCLE: multiple sequence alignment with high accuracy and high throughput. Nucleic Acids Res 32(5):1792-1797 
EEA (2009) Regional climate change and adaptation. The Alps facing the challenge of changing water resources. Copenhagen $143 \mathrm{p}$. http://www.riob.org/IMG/pdf/EEA_Report_8-2009_Alps.pdf. Accessed 20 May 2016

Eskildsen A, Carvalheiro LG, Kissling WD, Biesmeijer JC, Schweiger O, Høye TT (2015) Ecological specialization matters: longterm trends in butterfly species richness and assemblage composition depend on multiple functional traits. Divers Distrib 21:792-802

European Commission (2011) Our life insurance, our natural capital: an EU biodiversity strategy to 2020. COM 2011:244

Fox R, Brereton TM, Asher J, August TA, Botham MS, Bourn NAD, Cruickshanks KL, Bulman CR, Ellis S, Harrower CA, Middlebrook I, Noble DG, Powney GD, Randle Z, Warren MS, Roy DB (2015) The State of the UK's butterflies 2015. Butterfly Conservation and the Centre for Ecology \& Hydrology, Wareham

Garcia-Barros E (2002) Taxonomic patterns in the egg to body size allometry of butterflies and skippers (Papilionoidea \& Hesperiidae). Nota Lepidopterol 25:161-176

Garcia-Barros E, Romo Benito H (2010) The relationship between geographic range size and life history traits: is biogeographic history uncovered? A test using the Iberian butterflies. Ecography 33:392-401

Garibaldi LA, Steffan-Dewenter I, Winfree R, Aizen MA, Bommarco $R$ et al (2013) Wild pollinators enhance fruit set of crops regardless of honey bee abundance. Science 339:1608-1611

Gilbert A, Vincent C (2013) Atmospheric temperature changes over the 20th century at very high elevations in the European Alps from englacial temperatures. Geophys Res Lett 40:2102-2108

Guindon S, Dufayard JF, Lefort V, Anisimova M, Hordijk W, Gascuel O (2010) New algorithms and methods to estimate maximumlikelihood phylogenies: Assessing the Performance of PhyML 3.0. Syst Biol 59:307-321

Harvey PH, Pagel MD (1991) The comparative method in evolutionary biology, vol 239. Oxford University press, Oxford

Hedges SB, Dudley J, Kumar S (2006) Timetree: a public knowledgebase of divergence times among organisms. Bioinformatics 22:2971-2972

Ho LST, Ane C, Lachlan R, Tarpinian K, Feldman, R, Yu Q, Ho MLST (2016) Package 'phylolm\&\#8217

IUCN (2005) Guidelines for Using the IUCN Red List Categories and Criteria, IUCN-SSC http://www.iucn.org/webfiles/doc/SSC/ RedList/RedListGuidelines.pdf. Accessed December 2015

Ives AR, Garland T (2010) Phylogenetic logistic regression for binary dependent variables. Syst Biol 59:9-26

Janz N, Nylin S (2008) The oscillation hypothesis of host plant range and speciation. In: Tilmon KJ (ed) Specialization, speciation, and radiation: the evolutionary biology of herbivorous insects. University of California Press, Berkeley, CA, pp 203-215

Julliard R, Clavel J, Devictor V, Jiguet F, Couvet D (2006) Spatial segregation of specialists and generalists in bird communities. Ecol Lett 9:1237-1244

Karolewski P, Grzebyta J, Oleksyn J, Giertych MJ (2007) Effects of temperature on larval survival rate and duration of development of Lymantria monacha (L.) on needles of Pinus silvestris (L.) and of L. dispar (L.) on leaves of Quercus robur (L.). Pol. J Ecol 55:595-600

Keddy P, Nielsen K Weiher E, Lawson R (2002) Relative competitive performance of 63 species of terrestrial herbaceous plants. J Veg Sci 13:5-16

Keith DA, Rodríguez JP, Brooks TM, Burgman MA, Barrow EG, Bland L, Comer PJ, Franklin J, Link J, McCarthy MA, Miller RM, Murray NJ, Nel J, Nicholson E, Oliveira-Miranda MA, Regan TJ, Rodríguez-Clark KM, Rouget M, Spalding MD (2015) The IUCN red list of ecosystems: motivations, challenges, and applications. Conserv Lett 8:214-226
Kitahara M, Fujii K (2005) Analysis and understanding of butterfly community composition based on multivariate approaches and the concept of generalist/specialist strategies. Entomol Sci 8:137-149

Kolenikov S, Angeles G (2004) The use of discrete data in PCA: theory, simulations, and applications to socioeconomic indices. Carolina Population Center, University of North Carolina, Chapel Hill, pp 1-59

Kotiaho JS, Kaitala V, Komonen A, Päivinen J (2005) Predicting the risk of extinction from shared ecological characteristics. PNAS 8:1963-1967

Kraft NJB, Cornwell WK, Webb CO, Ackerly DD (2007) Trait evolution, community assembly, and the phylogenetic structure of ecological communities. Am Nat 170:271-283

Leingärtner A, Krauss J, Steffan-Dewenter I (2014) Species richness and trait composition of butterfly assemblages change along an altitudinal gradient. Oecologia 175:613-623

Lenoir J, Gégout JC, Guisan A, Vittoz P, Wohlgemuth T, Zimmermann NE, Dullinger S, Pauli H, Willner W, Grytnes JA, Virtanen R, Svenning JC (2010) Cross-scale analysis of the region effect on vascular plant species diversity in southern and northern European mountain ranges. PLoS ONE 5:1-13

Lindner M, Garcia-Gonzalo J, Kolström M, Green T, Reguera R, Maroschek M, Seidl R, Lexer MJ, Netherer S, Schopf A, Kremer A, Delzon S, Barbati A, Marchetti M, Corona P (2008) Impacts of climate change on European forests and options for adaptation. Report to the European Commission Directorate General for Agriculture and Rural Development p.173 http:// ec.europa.eu/agriculture/analysis/external/euro_forests/full_ report_en.pdf. Accessed 22 May 2016

Lütolf M, Bolliger J, Kienast F, Guisan A (2009) Scenario-based assessment of future land use change on butterfly species distributions. Biodiv Conserv 18:1329-1347

Maes D, Gilbert M, Titeux N, Goffart P, Dennis RLH (2003) Prediction of butterfly diversity hotspots in Belgium: a comparison of statistically focused and land use-focused models. J Biogeogr 30:1907-1920

Mattila N, Kaitala V, Komonen A, Kotiaho JS, Paivinen J (2006) Ecological determinants of distribution decline and risk of extinction in moths. Conserv Biol 20:1161-1168

Mattila M, Kotiaho JS, Kaitala V, Komonen A (2008) The use of ecological traits in extinction risk assessments: a case study on geometrid moths. Biol Conserv 141:2322-2328

Mattila N, Kaitala V, Komonen A, Paivinen J, Kotiaho JS (2011) Ecological correlates of distribution change and range shift in butterflies. Insect Conserv Diver 4:239-246

Moss D, Wyatt BK (1994) The CORINE biotopes project: a database for conservation of nature and wildlife in the European community. Appl Geogr 14(4):327-349

Mutanen M, Kivelä SM, Vos RA, Doorenweerd C, Ratnasingham S, Hausmann A, Huemer P, Dincă V, Van Nieukerken EJ, Lopez-Vaamonde C, Vila R, Aarvik L, Decaëns T, Efetov KA, Hebert PDN, Johnsen A, Karsholt O, Pentinsaari M, Rougerie R, Segerer A, Tarmann G, Zahiri R, Godfray HCJ (2016) Species-level para- and polyphyly in DNA barcode gene trees: Strong operational bias in European lepidoptera. Syst Biol 65:1024-1040

Nelson E, Mendoza G, Regetz J, Polasky S, Tallis J, Cameron DR, Chan KMA, Daily GC, Goldstein J, Kareiva PM, Londsdorf E, Naidoo R, Ricketts TH, Shaw MR (2009) Modeling multiple ecosystem services, biodiversity conservation, commodity production, and tradeoffs at landscape scales. Front Ecol Environ $7: 4-11$

Nemec J, Grube C, Chimani B, Auer I (2013) Trends in extreme temperature indices in Austria based on a new homogenised dataset. Int J Climatol 33:1538-1550 
Newbold T, Butchart SHM, Sekercioglu CHS, Purves DW, Scharlemann JPW (2012) Mapping functional traits: comparing abundance and presence-absence estimates at large spatial scales. PLoS ONE 7(8):e44019

Nieto - Sánchez S, Gutiérrez D, Wilson RJ (2015) Long- term change and spatial variation in butterfly communities over an elevational gradient: driven by climate, buffered by habitat. Divers Distrib 21:950-961

Ohlemüller R, Anderson BJ, Araujo MB, Butchart SHM, Kudrna O, Ridgely RS, Thomas C (2008) The coincidence of climatic and species rarity: high risk to small-range species from climate change. Biol Lett 4:568-572

Oyarzabal M, Paruelo JM, del Pino F, Oesterheld M, Lauenroth WK (2008) Trait differences between grass species along a climatic gradient in South and North America. J Veg Sci 19:183-192

Pagel, M (1999) The maximum likelihood approach to reconstructing ancestral character states of discrete characters on phylogenies. Syst Biol 48:612-622

Päivinen J, Grapputo A, Kaitala V, Komonen A, Kotiaho JS, Saarinen K, Wahlberg N (2005) Negative density distribution relationship in butterflies. BMC Biol 3:5

Parmesan C (2006) Ecological and evolutionary responses to recent climate change. Annu Rev Ecol Evol Syst 37:637-669

Pavoine S, Baguette M, Stevens VM, Leibold MA, Turlure C, Bonsall MB (2014) Life history traits, but not phylogeny, drive compositional patterns in a butterfly metacommunity. Ecology 95:3304-3313

Pinheiro J, Bates D, DebRoy S, Sarkar D, Heisterkamp S, Van Willigen B (2016) Package 'nlme'. Linear and nonlinear mixed effects models

Rasmont P, Franzén M, Lecocq T, Harpke A, Roberts S, Biesmeijer J, Castro L, Cederberg B, Dvorak L, Fitzpatrick Ú, Gonseth Y, Haubruge E, Mahé G, Manino A, Michez D, Neumayer J, Ødegaard F, Paukkunen J, Pawlikowski T, Potts S, Reemer M, Settele J, Straka J, Schweiger O (2015) Climatic risk and distribution atlas of European Bumblebees. BioRisk 10:1-236

Rodrigues ASL, Pilgrim JD, Lamoreux JF, Hoffman M, Brooks TM (2006) The value of the IUCN Red List for conservation. TREE 21:71-77

Rouault G, Candau JN, Lieutier F, Nageleisen LM, Martin JC, Warzée $\mathrm{N}$ (2006) Effects of drought and heat on forest insect populations in relation to the 2003 drought in Western Europe. Ann For Sci 63:613-624

Roy DB, Rothery P, Moss D, Pollard E, Thomas JA (2001) Butterfly numbers and weather: predicting historical trends in abundance and the future effects of climate change. J Anim Ecol 70:201-217

Sæther BE, Grøtan V, Engen S, Noble DG, Freckleton RP (2011) Rarity, life history and scaling of the dynamics in time and space of British birds. J Anim Ecol 80:215-224

Sall J, Creighton L, Lehman A (2005) JMP start statistics: a guide to statistics and data analysis using JMP and JMP IN software. Brooks/Cole-Thomson Learning, Belmont

Sanderson MJ (2003) r8s: Inferring absolute rates of molecular evolution and divergence times in the absence of a molecular clock. Bioinformatics 19:301-302

Schmitt T, Varga Z (2012) Extra-Mediterranean refugia: the rule and not the exception? Front Zool 9:22

Schweiger O, Harpke A, Wiemers M, Settele J (2014) CLIMBER: climatic niche characteristics of the butterflies in Europe. ZooKeys 367:65-84

Sekar S (2012) A meta-analysis of the traits affecting dispersal ability in butterflies: can wingspan be used as a proxy? J Anim Ecol 81:174-184

Settele J, Kudrna O, Harpke A, Kühn I, Van Swaay C et al (2008) Climatic risk atlas of European butterflies. Pensoft, Moscow
Shreeve TG, Dennis RLH, Roy DB, Moss D (2001) An ecological classification of Brittish butterflies: ecological attributes and biotope occupancy. J Insect Conserv 5:145-161

Stamatakis A (2014) RAxML version 8: a tool for phylogenetic analysis and post-analysis of large phylogenies. Bioinformatics 30(9):1312-1313

Summerville KS, Conoan CJ, Steichen RM (2006) Species traits as predictors of lepidopteran composition in restored and remnant tallgrass prairies. Ecol Appl 16:891-900

Symonds, MRE, Blomberg SP (2014) A primer on phylogenetic generalised least squares. Modern phylogenetic comparative methods and their application in evolutionary biology. Springer, Berlin-Heidelberg

Tavaré S (1986) Some probabilistic and statistical problems in the analysis of DNA sequences. Lectures on mathematics in the Life Sciences, vol 17. American Mathematical Society, Providence pp. 57-86

Thomas CD, Cameron A, Green RE, Bakkenes M, Beaumont LJ, Collingham YC, Erasmus BFN, de Siqueira MF, Grainger A, Hannah L, Hughes L, Huntley B, van Jaarsveld AS, Midgley GF, Miles L, OrtegaHuerta MA, Peterson AT, Phillips OL, Williams SE (2004) Extinction risk from climate change. Nature 427:145-148

Van Swaay C, Warren M, Loïs G (2006) Biotope use and trends of European butterflies. J Insect Conserv 10:189-209

Van Swaay C, Nowicki P, Settele J, van Strien AJ (2008) Butterfly monitoring in Europe: methods, applications and perspectives. Biodivers Conserv 17:3455-3469

Van Swaay C, Cuttelod A, Collins S, Maes D, López Munguira M, Šašić M, Settele J, Verovnik R, Verstrael T, Warren M, Wiemers M, Wynhof I (2010) European Red List of Butterflies. http:// ec.europa.eu/environment/nature/conservation/species/redlist/ downloads/European_butterflies.pdf. Accessed December 2015

Van Swaay C, Maes D, Collins S, Munguira ML, Sasic M, Settele J, Verovnik R, Warren M, Wiemers M, Wynhoff I, Cuttelod A (2011) Applying IUCN criteria to invertebrates: how red is the Red List of European butterflies? Biol Conserv 144:470-478

Van Swaay CAM, Termaat T, Kok J, Huskens K, Poot M (2016) Vlinders en libellen geteld. Jaarverslag 2015 (in Dutch). Report VS2016.001, De Vlinderstichting, Wageningen http://www. vlindernet.nl/doc/vs2016-001_vlinders_en_libellen_geteld_-jaarverslag_2015.pdf

Vanhanen H, Veteli TO, Pailvinen S, Kellomaki S, Niemala P (2007) Climate change and range shifts in two insect defoliators: gypsy moth and nun moth - a model study. Silva Fenn 41:621-638

Vasseur DA, DeLong JP, Gilbert B, Greig HS, Harley CDG, McCann KS, Savage V, Tunney TD, O'Connor MI (2014) Increased temperature variation poses a greater risk to species than climate warming. Proc R Soc B 281:20132612

Violle C, Navas ML, Vile D, Kazakou E, Fortunel C, Hummel I, Garnier E (2007) Let the concept of trait be functional! Oikos 116:882-892

WallisDeVries MF (2014) Linking species assemblages to environmental change: Moving beyond the specialist-generalist dichotomy. Basic Appl Ecol 15:279-287

Walther GR, Beißner S, Burga C (2005) Trends in the upward shift of alpine plants. J Veg Sci 16:541-548

Warren MS, Hill JK, Thomas JA, Asher J, Fox R, Huntley B, Roy DB, Telfer MG, Jeffcoate S, Harding P, Jeffcoate G, Willis SG, Greatorex-Davies JN, Moss D, Thomas CD (2001) Rapid responses of British butterflies to opposing forces of climate and habitat change. Nature 414:65-69

Willis KJ, Whittaker RJ (2000) Paleoecology-the refugial debate. Science 287:1406-1407

Wilson RJ, Gutiérrez D, Gutiérrez J, Martínez D, Agudo R, Monserrat VJ (2005) Changes to the elevational limits and extent 
of species ranges associated with climate change. Ecol Lett 8:1138-1146

Wright IJ, Reich PB, Westoby M, Akerly DD, Baruch Z, Bongers F, Cavender-Bares J, Chapin FS, Cornelissen JHC, Diemer M, Flexas J, Garnier E, Groom PK, Gulias J, Hikosaka K, Lamont
BB, Lee T, Lee W, Lusk C, Midgley JJ, Navas M-L, Niinemets U, Oleksyn J, Osada N, Poorter H, Poot P, Prior L, Pyankov VI, Roumet C, Thomas SC, Tjoelker MG, Veneklaas E, Villar R (2004) The worldwide leaf economics spectrum. Nature 428:821-827 